\title{
The dynamics of "post-crisis" spatial planning: a comparative study of office conversion policies in England and The Netherlands
}

\section{Article}

Accepted Version

Creative Commons: Attribution-Noncommercial-No Derivative Works 4.0

Remoy, H. and Street, E. (2018) The dynamics of "post-crisis" spatial planning: a comparative study of office conversion policies in England and The Netherlands. Land Use Policy, 77. pp. 811-820. ISSN 0264-8377 doi:

https://doi.org/10.1016/j.landusepol.2016.12.005 Available at https://centaur.reading.ac.uk/68405/

It is advisable to refer to the publisher's version if you intend to cite from the work. See Guidance on citing.

To link to this article DOI: http://dx.doi.org/10.1016/j.landusepol.2016.12.005

Publisher: Elsevier

All outputs in CentAUR are protected by Intellectual Property Rights law, including copyright law. Copyright and IPR is retained by the creators or other copyright holders. Terms and conditions for use of this material are defined in the End User Agreement. 


\section{CentAUR}

Central Archive at the University of Reading

Reading's research outputs online 
Paper prepared for a special issue of 'Land Use', on the 'Dilemma of dynamics in land policies', linked to the Academy on Land Governance for Equitable and Sustainable Development (LANDac) Conference, Utrecht 9-10 July 2015.

Paper title: 'The dynamics of 'post-crisis' spatial planning: a comparative study of office conversion policies in England and the Netherlands.

\begin{abstract}
Land policies governing individual and institutional rights to buildings and land are shaped by the socio-cultural, political and economic contexts within which they emerge and are (re)embedded within. This leads to considerable variation across place and space. Yet within this diversity commonalities emerge, not least in the 'rationales' that inform the development and implementation of land policies. These are explored via a comparative study of England - where market-based reforms have guided land use planning measures for some time - and the Netherlands; a country which is taking steps to introduce market-based values such as competition, efficiency and flexibility into its 'regulatory' spatial planning system (Evers, 2015). Through this comparison, we explore the way in which neoliberal political ideology and financial imperatives, sharpened by the 2008 global economic downturn, have resulted in changes to English and Dutch land policies. We illustrate this discussion by referring to land use policies under which authorities have sought to facilitate a change of land use, for example from office to residential usages. In both countries, these reforms have been introduced as part of attempts to make planning more 'efficient' and supportive of real estate markets. While there is variation in some of the drivers and apparatus used, we find parallels between the two countries' experiences. Our paper argues that fiscal austerity, economic uncertainty and the import of market values reproduces a shared reality of governance reform amongst the two countries, creating opportunities for critical learning between them.
\end{abstract}

\title{
Keywords
}

Land policy; Planning reforms; Permitted development rights; Governance

\section{Introduction}

Land policy can be understood as an assembly of governmental interventions in the allocation and distribution of land and other spatial resources (Davy, 2005; Needham, 2006; Hartmann and Spit, 2015). It is developed, and evolves in response to, a range of institutional, societal, financial and environmental triggers. In this paper, we show how financial drivers have combined with a (longer-standing) shift towards the neoliberalisation of spatial planning to prompt changes to land use policies in England and the Netherlands. These changes have the optimisation of land use and, relatedly, land value, as a clear goal. The land policy changes we focus on have been enacted through the English and Dutch spatial planning systems which themselves are the subject of on-going reforms. While there are significant differences between the two countries, both English and Dutch governments have claimed these reforms will deliver a planning system characterised by fewer rules, less governmental interference and more privately driven and financed developments.

The regulation of land uses through policy allows governments to assume control over issues as diverse as economic development, the conservation of historic or natural environments and the management of population growth. Yet, as Healey et al (1988) noted, this is a far from straightforward exercise: "the long-established values of amenity, of improving the quality of life as reflected in the design, facilities and spatial arrangement of the environment, co-exist uneasily with pressures for fewer restrictions on the location and design of new commercial, industrial and other projects" $(1988, x i)$. A central part of the planner's role is to try and balance these (often conflicting) objectives and pressures. Land policies are an important tool here and can take on a number of forms. Building upon Lichfield and Darrin- 
Drabkin's (1980) classification, Healey et al (1988: 3) identified three broad types of land policy: regulatory, developmental and financial. Albeit to differing extents, the British and Dutch spatial planning systems have generally favoured the use of regulatory tools, for example by overseeing specific schemes through the 'development control' system. This regulatory approach has been coupled with some developmental - for example, where authorities might purchase and develop land themselves - and financial measures, such as monetary incentives linked to zoning (ibid). This 'mix' of instrumentation is by no means static. In recent years, both England and the Netherlands have experienced changes in the pervading economic and political conditions. Such shifts can engender what Healey et al (1988) termed, 'new frames of reference' in spatial planning.

In this paper, we compare some recent changes to English and Dutch land policies. In both countries, these have been informed by neoliberal political ideology that privileges marketbased 'solutions' to public policy 'problems'. This emphasis has been heightened by a series of challenging economic events. Our primary focus in this paper is to assess the implications of these political and economic drivers on the planning of commercial office space. Significant events included the early 2000 'tech' or 'dotcom' recession which gave a correction to office markets across much of Europe and North America. While in buoyant markets like central London this was short-lived, the effects were still being felt in parts of outer London, some regional centres in England and across much of the Netherlands into the mid-2000s (Brounen and Jennen, 2009). This was followed by the 2008 global financial crisis. Together, these events had a significant impact upon the office market in lower value parts of England and across much of the Netherlands.

In the context of spatial planning, these economic drivers have fed into pre-existing reformist agendas in England and (more recently) the Netherlands that aim to stimulate real estate markets by dispensing of 'restrictive' regulatory tools. While the rhetoric underpinning planning reforms is one of de-regulation, following Roth (2015) we argue that this does not mean rules and regulations are dispensed with entirely. Indeed, as Roth (ibid) argues, welldesigned rules are essential in ensuring markets function 'optimally'. In England, such observations are particularly pertinent. The causes of the so-called housing crisis, whereby parts of the country are experiencing a chronic under-supply of suitable, affordable housing, are widely debated. Commentators have long-argued that low-levels of house building are evidence of market-failure (see MacLennan, 1982). However, in recent years the spatial planning system has attracted much of the blame for the crisis, with government cutting 'red tape' in order to 'free up' the property market.

With this context in mind, our paper considers recent changes to land policy in England and the Netherlands, arguing that reforms represent not a withdrawal of state intervention but instead a redesign of the rules. In both countries, these changes appear to be justified primarily as a way to stimulate property markets. The paper considers the differences and parallels between the two countries' approaches, and draws conclusions about these policies' benefits and risks, with a focus on initiatives linked to commercial office space.

The discussion of the English case focuses on the use of Permitted Development Rights (PDR), a policy allowing certain types of development to take place without the need for a planning permission. The first General Development Order was put in place around the time of the Town and Country Planning Act of 1947 (Booth, 2003). The 1947 Act established the modern town and country planning system and introduced the need to obtain planning permission for development to commence. Initially, the permissions granted under the GDO were minimal. As Booth (2003: p.103) notes, 'the tolerance allowed to the private developer was small...The householder might do little more without permission than put up small sheds and shelters in his garden (but not his garage)'. 
Permitted development policy has been altered over the years, often in line with the political flavour of the day. Since 1980, de-regulation has often been at the heart of these changes. As Prior et al (2007) note, permitted development and other land policy regulations have been devised to "exclude from planning controls minor development proposals which would generally have received planning permission, had an application been required' (p.22).

Operationally, the goal is to 'reduce the volume of development proposals submitted for planning permission, associated burdens on developers and planning authorities, thus assisting efficient development control without causing harm to amenity' (ibid). Apparatus such the PDR have been used by governments' looking to streamline the planning system, making it more supportive of development. The Conservative government of 1979-1997 revised the General Permitted Development Order allowing (for example) change of use from a public house to more profitable commercial offices as part a wider aim to reform the planning system and reduce the 'burden on business' (Cullingworth and Nadin, 2014; see also, Prior et al, 2007). The extent to which permitted development has evolved from the limited 'garden shed'-style permissions granted by the original General Development Order is evident.

In our view, the latest changes to the PDR that (amongst other things) are being used to stimulate land use change via the conversion of commercial buildings into residential usage, are a continuation of the pro-development logic espoused by the Conservative government of the 1980s were guided by. However, while the rhetoric of reform is certainly not new, it has been sharpened by the fall-out from the 2008 global financial crisis. In England, the Conservative-Liberal Democrat Coalition government (elected in 2010) made streamlining the planning system a key goal, arguing that this would stimulate economic growth and support the construction sector and delivery of new housing. In the words of the former Secretary of State for the Department of Communities and Local Government, the revised PDR were introduced as part of a series of measures designed to 'get Britain building again, to fix the broken housing market and to help hard-working people get the home they want' (Pickles, 2014: no page). Reducing redundant commercial office space was not as such a goal, but a positive side effect.

In the Netherlands, land policy changes have been driven by a slightly different set of factors. Namely, for our paper's focus, this was the 2001 office market downturn and the 2008 global financial crisis that together have led to high vacancy rates in (mainly) office real estate. A market failure critique was directed towards imbalance and overproduction in the office market (Brouwer, 1994; 2014). Remøy (2010) described a circle of blame, where developers blame office users who demand new-build, users blame investors who give them 'an offer they cannot refuse', investors blame the municipality who develop new land, and the municipality blames the developers who threaten to develop in the neighbouring municipality. The municipality acting as a 'market party' in this situation eventually shouldered much of the blame. In contrast to the office market, demand for housing and other functions within areas formerly designated for offices has remained more stable, driven by a low but steady population growth, household increase and urbanisation. Nevertheless, many of the same arguments were used in the Netherlands as in England, where the aim of reforms was to streamline the planning system in order to increase efficiency and thereby stimulate economic growth and support the construction sector. Moreover, an important aim for neoliberal policymaking was that streamlining the system would reduce the number of planners working as civil servants on all levels of government.

We continue this comparison of the Dutch and English contexts by discussing the theory behind the policies using two illustrative mini-cases, the London Borough of Croydon and the city of Rotterdam. We suggest that recent land policy reforms, of the kind seen in England and the Netherlands, are reflective of, and (re)produce, new frames of reference in spatial planning orientated towards market values; a discussion to which we now turn. 


\section{Post-crisis land-use planning in England and the Netherlands}

As Roodbol-Mekkes et al (2014) have suggested, the planning systems in England and the Netherlands have undergone significant reform in recent decades, with further changes planned in both countries. In England, spatial planning has been the subject of sustained attempts by government to transform planning from a 'reactive' and largely 'regulatory' activity, into a more proactive force for (economic) growth, environmental protection and enhanced social outcomes (see Clifford and Tewdr-Jones, 2011; Gunn and Vigar, 2012). Allmendinger and Haughton (2013) argue that while land use planning in the English context has long been 'market-supportive', a legacy of the Thatcher government's introduction of neo-liberal policies in the 1980s, recent reforms go further still. For them, spatial planning can now be seen as 'a form of, or contributor to, neoliberal spatial governance' (ibid: 6). Here neoliberalism is understood not as a singular 'thing', but instead as a 'fast evolving, multifaceted and spatially variable practices and policies to support a market-enabling approach' (ibid: 8).

Others point to a shift in spatial planning activities whereby local infrastructure and public goods such as social housing that were traditionally provided by the state instead became the responsibility of building producers and consumers, including property developers (Campbell et al, 2000: 760). Market values now sit firmly at the centre of the English planning system and can be understood as part of a wider process of governance reform in which the lines between private markets and the state have become ever more blurred. Pierre and Peters (2000) argue that one impact of this is the widespread adoption of an 'enabling' style of policy-making across many western governments since the 1990s whereby non-state agents, such as those within the private or third sectors, have taken on responsibility for the provision of a range of services previously operated within the public sector. While the extent to which this represents a wholesale disempowerment or erosion of state powers is debated (see Bell and Hindmoor, 2009) there is general agreement that, in countries like England where neoliberal thinking is well-established in policy, the role of the state can be understood as less overtly 'interventionist' than before.

In relation to the case of spatial planning and land policy in England, since May 2010 and the election of the Conservative-Liberal Democrat Coalition government ${ }^{1}$, a narrative of political decentralisation, pro-economic growth, deregulation and public sector cutbacks - in part a response to the global financial crisis of 2008 - has prevailed. This has informed the direction of land policy and other tools at planners' disposal. There have been several mechanisms driving this agenda of reform. A decentralisation of governance powers has been enacted via the Localism Act (2011) which 'sets out a series of measures with the potential to achieve a substantial and lasting shift in power away from central government and towards local people' (DCLG, 2011: 1). In the case of spatial planning, this has led to a complex and somewhat contradictory situation whereby new regulatory instruments such as neighbourhood-plan making ${ }^{2}$ powers have been introduced while the dismantling of the regional planning tier - historically the scale at which most strategic planning activity, including economic development planning, took place - has occurred.

Another significant policy change was the introduction of the National Planning Policy Framework in 2012. This is the latest in a long line of government attempts to simplify, modernise and arguably 'marketise' the English planning system (see Parker et al, 2014).

\footnotetext{
1 The Conservative party was re-elected as a majority government in the 2015 UK General Election.

2 Introduced under the Localism Act (2011), neighbourhood planning gives communities the power to make a neighbourhood development plan which establishes general planning policies for the development and use of land in a neighbourhood such as where new homes and offices should be build and what they should look like (see Legislation.gov.uk, 2012).
} 
The NPPF reflected the UK government's intention to cut red tape, streamline the planning process and establish the principle of 'pro-growth'. This is expressed in planning policy terms as the 'presumption' (i.e. to award planning approval) in favour of sustainable development. The NPPF has been accompanied by other measures to stimulate economic growth particularly in the construction sector which was severely impacted in the immediate aftermath of the global financial downturn. Following the removal of the regional planning tier, these measures have mainly emanated from central government and occasionally from the Treasury itself ${ }^{3}$. For example, the Growth and Infrastructure Act (2013) introduced a series of measures designed to reduce what the government described as 'confusing and overlapping red tape that delays and discourages business investment, housing development, new infrastructure and job creation' (DCLG, 2013: no page). This included provisions allowing property developers to renegotiate planning obligations ${ }^{4}$ - agreements that secure contributions towards local infrastructure and public goods such as affordable housing - where market conditions have changed making development 'unviable' and possibly stalling the delivery of schemes (see McAllister et al, 2016). Latterly, the controversial Housing and Planning Act (2016), which received Royal Assent following several months of parliamentary procedure including challenge in the House of Lords, introduces a range of measures designed to provide certainty for developers, particularly with regards to housing development. The Act includes 'Section 150', a new route for obtaining planning permission, which has been seen as "paving the way" for 'permission in principle' for certain types of housing-led development (Johnston, 2016: no page; Baker, 2016: no page).

This activity has taken place within a context of fiscal austerity, which has seen central government impose cutbacks of between $25-50 \%$ on local governments. 'Non-essential' services such as spatial planning have been hit especially hard with the majority of English councils seeing cuts of $46 \%$ between 2010/11-2014/15 to planning departments (NAO, 2014). As Parker et al (2014) note, one consequence of this reduced capacity in local authority planning departments has been the growth in the outsourcing of planning functions to the private sector. Arguably, this has been exacerbated by the pace at which legislative and policy changes have been imposed, with under-resourced planning departments often struggling to keep abreast of developments.

In the Netherlands, reforms to the planning system have been introduced more recently. As Faludi and Van der Valk (1994: xiii) acknowledged, spatial planning was perceived to be 'an art in which the Netherlands excels'. This view of Dutch planning practice began to change in the second half of the 1990's. Hajer and Zonneveld (2000) argued that the existing Dutch planning system was challenged by a series of developments. Some of these emanated from within planning itself, for example, practices evolved becoming more policy-led in nature. Socio-economic developments also played a role in challenging the Netherland's land-control oriented strategic planning. These changes were underpinned by wider shifts in thinking in line with a network-society approach. For example, as societal-economic developments were based on connectivity rather than proximity (one of the main concepts of the land-controlled strategic planning), this partly lead to more competition between city centres, highlighting the increased importance of spatial quality, and increased the involvement of stakeholders at

\footnotetext{
3 As opposed to the Department for Communities and Local Government (DCLG), responsible for spatial planning. The department experienced cuts of over 50\% to its budget between 2010-15, the largest cuts of any government department (Wheeler, 2015).

4 After indicating (in the Autumn 2015 budget) that the renegotiation mechanism would be retained, in April 2016 the government decided not to extend it saying that it was only a temporary measure designed to unlock 'unviable' sites. The decision not to make the renegotiation measure permanent may be due to a number of appeal cases between developers and planning authorities that were triggered by the introduction of Act (see Carpenter and Geoghegan, 2016).
} 
different levels, including private developers, large scale companies and citizen 'bottom-up' initiatives.

The Dutch planning system was rather complicated, involving the three levels of national, regional and local planning, using a series of indicative plans and elaborate consultations to generate agreement between the three levels. Within the new reality of the network society, the complexity of the planning system was becoming a hindrance to developers specifically and to the economic development of the building industry in general. As a result, reforms were found to be necessary to ensure efficiency. The new Spatial Planning Act of 2008 was part of a set of reforms that streamlined the planning system and transferred the control of spatial development to local government. As part of an attempt to make planning more efficient, the land use plan procedure was brought back from 58 to 26 weeks. This reform answered to what developers saw as one of the major obstacles for development; not only was the time aspect itself important, but the insecurity of the outcome of the procedure was a critical issue. The Spatial Planning Act was further adapted in 2012 to include the Sustainable Urbanisation Procedure, which further contributes to stimulate building conversion. According to this procedure, the need for new developments should be assessed on a regional scale. If indeed needed, new developments should be accommodated by area restructuring or transformation, and, on a detailed level, by building conversion. If the existing urban area offers insufficient potential, then sustainable new development is permitted (Ministry of Infrastructure and the Environment, 2011).

Further planning reforms were motivated by the 2008 financial crisis that had a severe impact on the building industry. These reforms, which included for example further planning efficiency measures, stimulating innovation and sustainability by flexibility in planning, testing planning reform measures that will be formally implemented in 2018, allowing experiments, reducing noise level requirements, and so on, were introduced as the Crisis and Recovery Act in 2010. The Act was to speed up development and encourage the realisation of urban and infrastructural projects. The Act removed or diminished many statutory elements, which were seen as 'procedural hindrances'. Amongst other measures, the ability of people to file a complaint against new developments was reduced. Whereas the housing shortage and unevenness in the national housing market are part of the picture of policy change in the English context, the Dutch Crisis and Recovery Act streamlined laws and regulations for conversion, gave municipalities the possibility to experiment with new planning tools, and enabled planned development capacity reduction without compensation claims (for example reduction of the planned capacity of offices). Following these reforms, the Environment and Planning Act will come into force in 2018. This is intended to make legislation simpler and more effective and will serve procedural and societal aims. The act consolidates 26 laws in the area of the physical environment, again as a measure to streamline the planning system according to the goal of increasing 'efficiency'.

As such, both the English and the Dutch planning system reforms are driven by a desire to intervene in, and bolster, real estate markets. Apart from the Crisis and Recovery Act, other measures were taken to promote development and re-use of existing or vacant buildings in the Dutch context (Hobma, 2013). The first was the implementation of the Sustainable Urbanisation Procedure. The second was an agreement that was signed by central and local governments and market parties in June 2012 to stimulate the withdrawal of offices from the office market by conversion, adaptation or demolition (Rijksoverheid, 2012). The third expanded the legal possibilities of temporary change of use of vacant office space, made possible by a change in the 'vacancy act' increasing the possibilities for temporary lease of vacant properties. The fourth was the implementation of the vacancy regulation based on the Squatting and Vacancy Act (kraken en leegstand, Stb. 2010, 320). Based on this Act, the owners of vacant properties could be obliged to notify and consult the municipality about new use of vacant office buildings. Henceforth, the municipality could oblige the owner to follow 
the municipality's advice. The fifth measure was to legally encourage residential conversion of offices. Juridical obstacles for this type of conversion had to be removed.

One obstacle for conversions was the Dutch building decree, which demanded new-build quality for housing units developed in existing buildings. From April $1^{\text {st }} 2012$ the building decree was amended with a specific quality level for renovations and conversions, but more often acknowledging the 'legally acquired level'. Briefly, this is the quality of the existing building before conversion. Without doubt, this benefits the financial viability of many conversion projects. On the other hand, the minimum technical quality is significantly reduced. Simplified: the quality of a new apartment in a converted office building from 1980 has the quality of the office as it stood in 1980. Hence, the problem may arise that the municipality must authorise conversions of relatively low quality. This means, following the Building Act 2012, significant differences in quality between new apartments and residential conversion apartments exist. The differences in quality requirements include minimum residential interior heights. For thermal and acoustic insulation, no minimum requirements apply to residential conversion. It could be argued that the building regulations pose only minimum requirements and that developers are free to choose to work to a higher level. However, research shows a correlation between the quality and the market segment that the private initiator develops for (Arcadis, 2013). This suggests that residential conversions for lower market segments are likely to be realised according to the lowest possible quality, i.e. the level legally required.

What both the English and Dutch cases have in common is a concern, sharpened in the post-financial crisis climate, to (re)orientate land policy more explicitly towards servicing the needs of the property market. Easing the path for commercial office buildings to be converted into other 'more productive' uses via revised land use policy is one tool used to achieve this. In the Netherlands, market driven developments are, not surprisingly, seen as the way to improve the feasibility of residential conversion, with municipal support regardless of the location or situation of the planned conversion (Remøy et al 2015). The new Environment and Planning Act that will come into force in 2018 will streamline the Dutch planning regulations further towards a system where the local government has little official steering possibilities, and will therefore take the Netherlands closer still to the English, where the revised Permitted Development Rights (PDR) were introduced nationally in order to increase the number of office to residential conversions, a discussion to which we now turn.

\section{The case of permitted development rights}

In keeping with the English government's drive to streamline the planning process, increase efficiency and drive forward development including unlocking sites 'stalled' as a result of weakened market conditions (see McAllister at el, 2016), temporary revisions were made to the PDR in 2013. The PDR are a national grant of planning permission which allow certain building works and changes of use to be carried out without the need to obtain a formal planning permission (provided certain conditions are met). One application of the PDR is to facilitate the change of use of land and buildings. The Town and Country Planning (Use Classes) Order 1987 puts uses of land and buildings into four main categories (which are further divided into a number of subclasses):

- Class A covers shops and other retail premises such as restaurants and bank branches;

- Class B covers offices, workshops, factories and warehouses;

- Class C covers residential uses; and

- Class D covers non-residential institutions and assembly and leisure uses.

Following an initial 3-year trial period, the Town and Country Planning (General Permitted Development) (England) Order 2015 granted permitted development rights for change of use where planning permission is not needed for changes in use of buildings within each 
subclass and for certain changes of use between some of the classes. One practical application of the 'new' PDR is that a 'planning permission' or planning consent is not needed for the conversion of offices into residential usage. In some instances this has had a stimulatory market effect since once application of this revision is that, in principle, it facilitates the conversion of existing office space (that may have been un- or under-used) into higher-yielding residential spaces, in turn supporting the delivery of more housing units.

De-regulatory measures such as the revised PDR are consistent with a line of argument propounded over the last 30 or so years, in which the planning system has been accused of impeding the delivery of new housing through the private sector. Private sector developers have become more central to the delivery of units as housing policy reforms such as the widespread sell-off of public (council) housing have reduced the stock of social housing available to local authorities to meet demand. While the assumption seems to have been that industry house-builders will step up production to maintain supply, levels of house-building has remained below the levels needed to meet with demand for many years (see DCLG, 2015a). This, combined with the soaring house prices seen across much of southern England (and other high value pockets across the country) since the mid-2000s and only momentarily tempered by the crash of 2008 , has created a 'perfect storm' of unaffordability.

England's Chief Planner claimed the revised PDR could help to address the housing crisis by creating more than 32,000 additional units across England (Carpenter, 2014). However, the rules are not removed entirely; a developer needs local government to approve that the project complies with a series of tests for prior approval. Hereto information should be provided about the project to ensure that it is not located on contaminated land, within an area of high flood risk, with expected traffic problems or congestion, with a high external safety risk and, since April 2016, with noise levels that might impact upon residents. If this is the case, the local planning authority could stop the development ${ }^{5}$. Moreover, the 'order' is not applicable to all areas. Local authorities can lay down an Article 4 direction giving them exemption from the permitted development rights in certain areas, for example, areas of high demand for office space.. In these exempted areas, a planning permission is still demanded to avoid the situation where owners and investors choose to change the land use from offices to the higher yielding housing function.

For example, the London Borough of Croydon planned to introduce an Article 4 direction in the town centre to exempt this area from the PDR. However, while the new policy took effect, several new applications for office-to-residential conversions were lodged (Agbonlahor, 2015). Central government also retains the right to intervene and modify Article 4 Directions if it perceives them to be 'inappropriate' or 'disproportionate' (London Councils, 2015). This indicates that local authorities may still face problems managing the impacts of the policy, even when exemptions are sought. PDR can also impact upon authorities' ability to meet affordable housing demand in their local areas. This is because, provided matters requiring prior approval are satisfactorily addressed, permitted development should already be acceptable in planning terms. This means that planning obligations, designed to mitigate the negative impacts of development via developer contributions to local infrastructure including affordable housing, do not normally apply to permitted development 6 . This means that contributions that would be generated by development to fund the impacts of development locally are lost to local authorities, potentially adding to the pressure placed upon existing infrastructure and local services. The scale of this problem is hard to ascertain, but analysis conducted by the London Boroughs indicates that prior approval has been granted for the conversion of at least 7,000 new dwellings in schemes of 10 units or more (London Councils, 2015). Had these dwellings been delivered via the planning system, around 1,000 new

5 Listed buildings are also exempt from the PDR (Hobma, 2013).

6 Permitted development may be subject to charges under the Community Infrastructure Levy (CIL), depending on when development commenced and the status of the relevant local authority's CIL charging schedule. 
affordable homes or equivalent Section 106 developer contributions on other sites would have been expected to be recouped (ibid). One perspective is that, while additional units may be provided via the PDR, the absence of developer contributions represents a loss to Boroughs that are already facing difficulties in meeting levels of demand for affordable housing.

With regards to issues of quality, the Building Regulations which set out the rules making new and converted buildings safe and accessible and to limit waste and environmental damage, remain applicable to the residential conversion of offices. This should ensure that 'minimum standards' are (at least) adhered to. However, the more complex (and costly) practice of 'place making' is likely to be compromised as mechanisms to prompt anything other than the lowest common denominator in terms of quality standards is absent. As a report by the London Councils (2015) suggests: 'As residential conversions are no longer required to be plan-compliant, many unsustainable and poor quality schemes have been brought forward, with the local planning authority having no power to ensure they meet basic standards such as minimum space and adequate light and ventilation' (no page).

Planners' ability to ensure that residential conversions are located in a sustainable location is also compromised. This could mean that housing delivered through the PDR could be realised in undesirable places, i.e. far removed from social facilities like schools and health care, transport infrastructure or daily necessities like supermarkets. While in principle quality and sustainability are protected by the so-called 'golden thread' of sustainable development that runs through English planning policy, in curtailing planners' ability to consider how issues of demand, viability, quality etc. are balanced, there is a risk of the lowest common denominator prevailing and unsustainable development occurring.

There are also concerns that the PDR could, somewhat ironically given the government's focus on stimulating economic activity, compromise economic development planning by undermining authorities' ability to plan for, and respond to, demand for commercial office space. Such fears were expressed by the former London Mayor Boris Johnson who, responding to the government's consultation on the proposals to revise the PDR commented: 'I am concerned that removing the exemption in our most thriving business districts could compromise both London and the UK's future economic growth. London's success depends on a rich mix of uses and more high value residential property in central London could upset this balance and change the area for good' (GLA, 2014: no page). Indeed, research conducted by the property consultancy Lambert Smith Hampton showed that more than 11 million square feet of office space has been allocated for alternative uses since the introduction of the new PDR (LSH, 2015). Additionally, it is argued that conversion into housing is now pricing out start-ups and small and medium sized enterprises in central London and other UK cities, triggering gentrification and threatening the local creative economy (Green, 2015). A London Councils report estimates that, in the capital, prior approval has been granted for at least $100,000 \mathrm{sq} \mathrm{m}$ of wholly occupied office floor space between May 2013 and April 2015, and 834,000 sq m total office floor space, 'threatening the viability of office redevelopment and refurbishment even in areas where there is clear demand' (no page). Others, such as the Royal Town Planning Institute, have raised concerns that employment opportunities are being displaced in some areas as a result of the take up of the PDR (Dewar, 2016) as planning for a sustainable mix of residential and commercial / employment uses is made very difficult.

The goal of the English scheme is consistent with post-crisis reforms seen in various aspects of the spatial planning system. The over-riding goal is to stimulate development, in this case by making it easier for developers to convert vacant offices by removing the perceived barrier of obtaining planning permission. This is an important point and gets the heart of recent discussion about the role of planning in delivering growth. Indeed, while the 'value' of planning has been debated fiercely since at least the first Town and Country Planning Act of 
1947 (and arguably before), the period from 2010 onwards has seen perhaps the most overt and sustained period of attack on the merits of spatial planning. Indeed, even the former Secretary of State with responsibility for planning has been clear about planning being the 'problem' (therefore rationalising its streamlining or even removal) rather than part of the solution (see Pickles, 2011: no page).

Returning to the case of PDR itself, the amendment means that the speed of residential conversion procedures can be accelerated, reducing the costs of such conversions. Moreover, one of the most important perceived barriers for conversions according to developers (Remøy, 2010) - the need to obtain planning approval - is removed, and could have a positive impact on the willingness of developers to get involved in residential conversions. Initial take-up of the new PDR suggests that there was indeed a demand for the revised approach. Government forecasting estimated that up to 190 office conversions would take place across England under the new system per year (Carpenter, 2014: no page). However, research by the Planning Resource conducted between May 2013 and July 2014 showed that levels far exceeded this, with the London boroughs receiving 2,005 prior approval applications to convert offices to homes. An additional 269 applications were received over the same period in the 10 core cities of Birmingham, Bristol, Leeds, Liverpool, Newcastle, Manchester and Sheffield, amounting to a total of 17,500 homes. Levels appeared to be slowing down into the first quarter of 2015, with official DCLG figures indicating that 828 office-to-residential prior approval applications had been received, down from 999 in the last quarter of 2014 (DCLG, 2015b).

While some statistics about the use of the PDR are emerging at a national scale, research about the impacts of the policy at a more local / urban-scale is very limited. In the following section we outline the two case study areas, Croydon in south London, and Rotterdam in the Netherlands, through which we explore the effects of recent land policy changes in more detail.

\section{Methodology}

Case studies are well suited to comparative studies of localised impacts in that they can focus on either single or multiple cases, have the capacity to explain causal links, depend on theory development in the research design phase, rely on multiple sources of evidence and finally, can be used to generalise empirical findings to theory (for an overview, see Yin, 2013). This supports our aim to draw parallels between the English and Dutch contexts, searching for points of synergy and divergence. The cases studied are Croydon, a borough in outer London, and Rotterdam, the Netherland's second city. Croydon has a $50 \%$ office vacancy rate in the borough-centre (Croydon Metropolitan Centre, 2015) that is even higher than the vacancy in central Rotterdam, which is around 20\% (DTZ, 2015).

As described above, the land policy changes studied in both cases are triggered by central government attempts to deliver effective land use planning in a context of financial uncertainty. Case study data were generated through the analysis of key documents and plans, and supplemented by interviews. For the Croydon case, semi-structured interviews were held with 2 representatives from the planning department. Information about on-going conversions was gathered from the planning department. In Rotterdam, 2 municipal planners were interviewed, using a semi-structured interview protocol. Both were part of a team from the Urban Development Department that was assigned to stimulate land use change developments. Also in Rotterdam, data about completed and on-going conversions were collected at the planning office. Additionally, real estate developers and investors who had already completed office to residential conversions were interviewed. The effect and efficiency of the new policy measures were discussed with planners, while conversations with private parties in Rotterdam were focussed on their experience the new policy. 


\section{a. The impact of the new Permitted Development Rights: the case of Croydon}

Croydon is a South London borough and is identified as one of 11 metropolitan centres in Greater London (Greater London Authority). While Croydon had an office vacancy rate of more than 50\% in the years 2013-2015 (Croydon Metropolitan Centre, 2015), new office properties are still being developed. In 2013, permits were given for the development of more than $20000 \mathrm{~m} 2$ new office space. Developers state that the quality of the existing stock is too low to attract new office users, and that new office buildings are needed. Meanwhile, under the PDR, offices are being withdrawn from the market and converted into housing. The conversion of vacant offices could deliver significantly to the London Borough of Croydon's target of delivering 20,200 homes between 2011-2021 (LB Croydon, 2013). Some of these conversions received planning consent by going through the full planning process. However, since the revised PDR were established, most conversions have gone through as part of this. In 2013 and 2014, 1343 residential units were planned in 28 schemes according to the PDR. Of these, $58 \%$ were one-bedroom apartments, $33 \%$ were two bedroom apartments, $8 \%$ were studios and just $1 \%$ were larger apartments (Croydon Planning Service, interview 2014). Only $17 \%$ of the residential units meet the floor space requirements for housing set out in the Mayor of London's (2016) London Plan which acts as the spatial development strategy for London. Only nine of the units have any form of private or communal amenity space impacting upon place-making goals. As the conversions are effectively planned outside of the planning system, they do not contribute towards social infrastructure requirements like affordable housing.

Those involved in the provision of Croydon's spatial planning service are worried about the developments, and has signalled some negative externalities as possible results of the PDR conversions. In an interview, the Croydon Placemaking team expressed the broader concerns of Croydon Council: First, developers who were involved in conversions that were dealt with according to the full planning process are backing out of developments. They worry that the low quality of PDR conversions will give a negative stigma to all conversions. Moreover, it seems unfair to them that they contribute to social infrastructure whereas PDR developments do not, and the financial benefits of developing within the full planning process are lower. Lower general quality of housing in Croydon could be the effect. Second, the municipality is losing control of important aspects the spatial planning process. The municipality has no instrument to steer PDR conversion to or away from specific locations, and fears that buildings in potentially good office locations, e.g. next to train station, may be converted to low quality housing, which will again have a negative effect on the vacancy and rental price of surrounding office properties. The London Borough of Croydon wishes to withdraw the PDR for central Croydon, using the article 4, but so far it has not been successful (Croydon Planning Service, interview 2014). One of the criteria for the use of Article 4 is the office vacancy rate in the area and, as Croydon has high levels of office vacancy, its use has been rejected based on market conditions.

The effect of the PDR in Croydon reveals the dilemma facing spatial planning authorities. On the one hand, office vacancy leads to obsolescence and the depreciation of the property's value, and may also have a negative impact on the rental prices and value of neighbouring properties (Koppels, Remøy and El Messlaki, 2011, Remøy, 2010). On the other hand, the quality of conversions that take place outside of the official planning process cannot be guaranteed. One worrying scenario is that, given how difficult good place making is under the revised PDR, these conversions will become areas of blight in future years, presenting further challenges for planning authorities. Turning now to the situation in the Netherlands, four measures following the Crisis and Recovery Act of $2010^{7}$ have had effects similar to the

\footnotetext{
71 , agreement to stimulate the withdrawal of offices from the office market, by conversion, adaptation or demolition, 2, the 'vacancy act' increasing the possibilities for temporary lease of vacant properties,
} 
PDR in England. In the following section we use the case of Rotterdam to illustrate the effect that these measures have had.

\section{b. Covenant and soft measures: the case of Rotterdam}

Rotterdam is the Netherlands second biggest city. Since 2008, vacancy rates in the office market have increased to almost 20 percent. This is much higher than the 3-8 percent that is seen as a normal level of vacancy needed to enable transactions in the market. To reduce vacancy and enhance the liveability of the city centre, the Rotterdam Urban Development Department has had a team assigned to stimulate land use change developments, including conversions from offices to residential, since 2011. The most important guideline for the team was a covenant between the municipality and market parties, directed towards the conversion of vacant offices. The covenant stated targets for 1) square metres to be converted, 2) square metres converted should be higher than square metres new-build offices, and 3) knowledge sharing between the municipality and market parties should be increased; the municipality should become a knowledge centre facilitating private parties. The covenant upheld the concept of 'best effort obligations'. This means that no 'hard targets' were given for the market parties, and no measures would be taken to penalise parties who did not adhere to the covenant. The urban planning and economy alderman, responsible for the covenant, stated 'the covenant was intended to get market parties moving, and moving fast. If we attach hard targets to the covenant, they would confer with their lawyers and 4 years later, still nothing would have happened. This way, everyone was enthusiastic and took action right away' (Remøy et al, 2015: 8). At the end of the covenant, all of the initial targets set were achieved.

During the covenant term (2011-2015), national legislative changes were implemented that were in favour of conversion. The most important changes were made as part of the Building Decree 2012 which set a new quality level for conversions and renovations (as explained in section 2). Another important amendment was made to the Environmental Law Decree 2014, which effectively enables the terms of the land use plan to be waived more easily. Additionally, the required timespan of municipal procedures was shortened. This way, municipalities have more freedom to promote conversions. After a change to the Environmental Planning Act (in November 2014) the land use plan lost some of its effect. Although the municipality must approve all land use changes, the land use change application does not have to be accompanied by a spatial quality motivation, as was the case before 2012. This means that, more like the effect of the PDR in England, although planners can reject a conversion scheme, it cannot be rejected based on the (lack of) quality of the development. Hence, unsustainable and poor quality conversions can be developed in undesirable places, i.e. far removed from social facilities or local infrastructure. Private parties often opt for redevelopment into functions that have a high yield, whereas the municipal planning department looks to add functions that contribute to the spatial quality of an urban area creating a potential conflict.

Other important issues for spatial planning departments are managing the demand for new uses, and (keeping or upgrading) the architectural and technical quality of the converted buildings. Especially in central urban areas, the municipality advocates the use of spatial and building quality as criteria for land use change, in order to enhance the attractiveness of the city. However, according to the recent amendments, changes to the land use plan cannot be rejected based on insufficient spatial, urban, and architectural quality. Some municipal steering tools still exist though. The municipal parking regulations can be used, together with air quality and noise nuisance regulations, the architectural review committee's advice, and, in the case of listed buildings, the cultural heritage preservation act (which is legally binding).

3 , the implementation of the vacancy regulation based on the 'Squatting and Vacancy Act' (kraken en leegstand, Stb. 2010, 320). 4, to legally encourage residential conversion of offices. 
Altogether, this means that it has become more difficult for municipalities to steer urban development according to local wishes. Whereas the planning regulations have become simpler on the larger scale this means less room to manoeuvre for the local government.

The Rotterdam covenant was part of the city's vacancy policy from 2011 to 2014 and was reflected in the new programme vacancy policy (2014-2016), wherein the municipality states its aim to match planned new developments to demand, use new construction to improve urban quality, deploy temporary use and conversions for urban redevelopment, and to continue stimulating and acquiring conversions in collaboration with market parties. In the period in which the covenant was effective, the cooperation between the municipality and market parties improved significantly (Remøy et al, 2015). The market parties who had signed the covenant felt involved and responsible. All market parties reported being pleased with the work of the 'transformation team'; the team assigned to pull land use change developments, and ascribed successful redevelopments partly to the team's work. Cooperation in urban redevelopment was the main success factor. Albeit many obstacles for conversions were removed at the municipal level, private parties still see strict building regulations and procedures as bottlenecks for conversions.

For the municipality, stimulating building conversion as an approach to reduce office vacancy, increase housing density and enhance spatial quality in the city centre and central urban areas has worked out well. Due to the pro-active involvement of the Urban Development Department, more than $200000 \mathrm{~m} 2$ of vacant offices were converted into housing and other functions. The municipality has so far kept control over planning. While traditional planning tools such as strict environmental plans, land use plans and building decree are losing their effect, the municipality of Rotterdam has developed its own steering tools for land use remedying some of the restrictions that the changes enacted by national government have placed on those responsible for planning and development at the local / urban scale. These are 'soft' tools based on decision making by agreement and acceptance, consisting of dialogue, co-creation and cooperation. None of the tools are based on legal agreements, but on trust and transparency. Effectiveness and efficiency are still the aims of the land policy, though their efficacy is yet to proven.

\section{Discussion}

The English PDR scheme is more or less comparable to the list of work that has been effectively 'waived' according to the Dutch Environmental Planning Decree of 2010. Although this simplified the building permit application procedure, it did not lead to more office to residential conversions. The most important obstacle to this was found to be the building decree, which required new-build quality (Stadig and Minderhoud, 2011). The building decree of 2012 (current) defines a specific quality level for renovation and conversion. For this reason, policy makers are less concerned that residential conversions may become blighted. It is also the case that housing demand in the Netherlands is much lower than in London, and the pressure on the housing market and on the supply of affordable housing is lower. Policy makers therefore have more trust in market forces; if quality is low, people have a choice not to let/rent or buy. However, quality at an urban level might still be at stake. Until 2012, municipalities had more opportunities to reject conversion plans with a lower quality level than new-build. As such, the building decree was an important planning instrument. If the spatial planning department thought the conversion made a positive contribution to urban development, exemptions were given more often than not (Remøy et al, 2015). However, within the regulatory framework of the current 2012 building decree, the municipality is less able to use this instrument to steer conversions to a high quality level.

Moreover, planning procedures were simplified. After a change to the Environmental Planning Decree (in November 2014), deviation of a land-use plan - for instance changing 
land-use from offices to residential - need no longer to be substantiated by a spatial motivation. In effect, the wider spatial effects of re-use into apartments need not be examined. On top of that, procedures for re-use have been considerably quickened. For reuse of vacant buildings, an 8-week procedure applies, whereas previously procedures lasted 6 months. The air quality and noise in the location are now the only factors that could lead to a rejection of the conversion. So far, the effects of these new regulations and policies are hard to measure. Following the global financial crisis, activity in the Dutch construction industry was low, and demand for housing stagnated. A recovering economy and building industry will show what the effects of the Crisis and Recovery Act and related regulations will be in the long run.

Table 1: Summary of relevant policies, key features and outcomes

\begin{tabular}{|c|c|c|}
\hline & England / Croydon & The Netherlands / Rotterdam \\
\hline Policy: National & $\begin{array}{l}\text { a) Town and Country } \\
\text { Planning (General } \\
\text { Permitted Development) } \\
\text { (England) Order 2015 } \\
\text { b) National Planning Policy } \\
\text { Framework (2012) } \\
\text { c) Localism Act (2011) and } \\
\text { d) Growth } \quad \text { Infrastructure Act (2013) } \\
\text { e) Housing and Planning } \\
\text { Act (2016) }\end{array}$ & $\begin{array}{ll}\text { f) Spatial Planning Act } 2008 \\
\text { g) Crisis and recovery act } \\
2010 \\
\text { h) Squatting and Vacancy } \\
\text { Act } 2010 \\
\text { i) Spatial Planning Act } 2012 \text {, } \\
\text { including Sustainable } \\
\text { Urbanisation Procedure } \\
\text { j) } \text { Building Act } 2012 \\
\text { k) Environmental law decree } \\
\\
2014\end{array}$ \\
\hline Policy: Municipal & $\begin{array}{l}\text { I) Article } 4 \text { Direction } \\
\text { (restricts the application } \\
\text { of the PDR) }\end{array}$ & $\begin{array}{l}\text { - Land use plan } \\
\text { m) Covenant } \\
\text { n) Local steering through } \\
\text { dialogue }\end{array}$ \\
\hline Key features: & $\begin{array}{l}\text { a) Certain types of work } \\
\text { can be carried out } \\
\text { without needing to apply } \\
\text { for planning permission; } \\
\text { facilitate the change of } \\
\text { use of land and } \\
\text { buildings } \\
\text { b) Presumption in favour of } \\
\text { sustainable } \\
\text { development } \\
\text { c) Measures to devolve } \\
\text { powers including } \\
\text { planning to local people } \\
\text { d) Provisions to promote } \\
\text { growth in infrastructure } \\
\text { and development } \\
\text { e) Legal changes primarily } \\
\text { aimed to support the } \\
\text { supply of new homes }\end{array}$ & $\begin{array}{l}\text { f) Streamline planning } \\
\text { procedures } \\
\text { g) Reduce planning } \\
\text { procedure time } \\
\text { h) More flexible land use } \\
\text { plan } \\
\text { i) Improve sustainability } \\
\text { j) Ease conversion }\end{array}$ \\
\hline Outcomes - office space & $\begin{array}{l}\text { + Conversion of office space } \\
\text { into residential use } \\
+ \text { Reduction of office } \\
\text { vacancy } \\
\text { - Loss of office stock in }\end{array}$ & $\begin{array}{l}+ \text { Conversion of office space } \\
\text { into residential use } \\
+ \text { Reduction of office vacancy } \\
+ \text { Improvement of urban } \\
\text { quality }\end{array}$ \\
\hline
\end{tabular}




\begin{tabular}{|l|l|l|}
\hline & $\begin{array}{l}\text { desirable locations } \\
\text { - Reduction of urban quality } \\
\text { - Unsustainable } \\
\text { development } \\
\text { - Less grip on the direction } \\
\text { of urban development }\end{array}$ & $\begin{array}{l}\text { - Less grip on the direction of } \\
\text { urban development }\end{array}$ \\
\hline
\end{tabular}

\section{Lessons}

Land policy provides a framework for spatial developments (Needham and Hartmann, 2012). In both England and the Netherlands, land policies are operationalized via the spatial planning system which, as this paper has shown, has undergone significant reform in recent years. The examples we have focussed on demonstrate how land use policy - specifically measures guiding the use of buildings - forms a central part of wider legislative changes. In the wake of the global financial crisis (and to a lesser extent the earlier 'tech' crisis) this was informed by a desire to kick-start 'stalled' development and address housing shortages in the English context, and to support the conversion of un- or under-occupied commercial office spaces in the Dutch context.

Both examples show how central government legislation for land policy has had an impact on local governments' ability to steer land uses and to effect land use changes. In the English context this could be seen to undermine claims made in the Localism Act (2011) that greater control for effective planning and place-making has been devolved to the local level. In the Rotterdam case, the balance of power between municipalities and developers appears to be more positive, although this could be explained by the role Dutch planners are assuming by aiming to stimulate economic development, again showing a move away from the hallmarks of Dutch strategic planning historically. Being a second-tier city, the local municipality has shown the ability to improvise and has demonstrated readiness to cooperate with and support developers and other private parties. Taking on an active role facilitating private developments has given the municipality the possibility to steer developments through dialogue where 'hard' policy measures have been eradicated.

The experience of the amended Permitted Development Rights in England may offer some formative lessons for the Netherlands, which despite being feted the world over for its ability to plan for and deliver high-quality and sustainable places, appears to be set on a path of reform that is now fairly well-trodden in England. This seems to be the case despite concerns that recent changes to English planning policy are failing to prevent inappropriate and unsustainable development (HCCLGC, 2014). While land policy instrumentation in the two countries may be different, the language of reform is surprisingly similar and reflects shared neoliberal values and claims about efficiency, public sector shrinkage, flexibility and so on that has seems to have become even more pervasive post-financial crisis. More pointedly, the case of changes to permitted development rights provides us with an opportunity to reflect upon the following issues:

- The interdependent nature of land policy and planners' autonomy;

- The balance of power between market actors such as property developers and planners;

- The impact (intended or otherwise) of land-use reforms upon economic development; sustainable development and the provision of commercial office space in particular;

- The quality and affordability of inner-urban housing as a consequence of not being able to impose planning obligations

Our analysis is that the revised PDR, and legislative steps taken to increase occupancy in the Dutch case, superficially lessen the role of the government, in that the local authority 
needs only to check that the conversion complies with the tests for prior approval. In theory, this removes the 'barrier' of needing to obtain planning approval for developers and sets the tone for a more market-orientated approach to land use policy. However, as Roth (2015) notes, in supporting free market activity, rules are not removed so much as re-designed. Indeed, as Prior and Raemaekers point out, 'planning regulation...does not seek an absolute level of prohibition of adverse environmental impacts. Instead, it seeks a level of environmental protection consistent with minimal state interference with development rights, and the maintenance of workable, pragmatic relationships between regulator and regulated' (p257). For example, while the revised PDR offer the potential to increase housing unit supply (and therefore stimulate property market activity), while appearing to simplify the situation, the revised rules actually introduce a number of complications. In this sense, their ability to ensure that (property) markets operate 'optimally' (Roth, 2015) is questionable.

With that said, flexibilities, such as the Article 4 option, do exist within the English policy example. This is a notable difference between England and the Netherlands. The new Dutch legislation (New Building Decree 2012, Environmental Law Decree 2014) has less opportunity for modification at the local municipal scale, and the revisions open up opportunities for land use change and for residential conversion similar to the PDR. Until now, whereas some English towns and boroughs have experienced the downside of reduced 'public steering', the Netherlands seems to have had more positive experiences. Consequently, government are looking at how to remove even more 'planning obstacles'. One of the reasons for this more positive picture could be the Netherland's greater availability of more affordable housing and hence less spatial pressure on Dutch urban areas. If these triggers increase in intensity, it is possible that the Netherlands could face a comparative level of pressure as currently being experienced in parts of England. In this sense, caution is required before further land use policy reforms are pursued. As the revised PDR have shown, 'rolling back' legislation to give the market (even if only theoretically) more room for manoeuvre is both hard to achieve and can lead to harmful contradictions in policy goals, creating new challenges in the achievement of effective spatial planning.

This paper has highlighted the power of land policy (both real and potential) to intervene in the functioning of property markets. A goal of these policies has been to bolster the strength of commercial and residential real estate markets that were shaken in aftermath of economic downturns. Relatedly, one consequence of the revised PDR and the new Dutch building and environmental law decrees, has been to shift the distribution of responsibilities between central planning authorities and municipalities, and other players such as property developers. This raises questions about the legitimacy of spatial planning as an activity that is supposedly performed on behalf of the wider 'public interest'. In both the English and the Dutch context, post-crisis, planning policy has very much operated according to an 'economic recovery' logic while social, economic and environmental targets have been comparatively neglected (Raco and Street, 2012; HCCLGC, 2014). The extent to which this constitutes a longer-term threat to the future of spatial planning in Europe is not yet clear. In England, the passing of the Housing and Planning Act (2016) suggests that the government's appetite for de-regulating planning functions, in this case rationalised as necessary in order to support the development of new homes, remains undimmed.

Our study of the impacts of land policy reforms highlight a wider challenge for spatial planning; namely, how to balance economic efficiency with 'softer' (but arguably no less important) aims such as quality of life and public participation. These are the 'wicked problems' that spatial planners continue to grapple with as they look to deliver sustainable development. Land policies form an important part of this context. The revised PDR and Dutch land use policy reforms may appear mundane or even inconsequential when we consider the myriad challenges facing urban environments, yet they can be viewed as part of a wider 'redesign' of the rules in order to stimulate property markets. Or, to use Healey et al's (1988) terminology, land policy is a contributing factor in the creation of 'new frames of 
reference' in spatial planning. In this sense, being attuned to the impacts of land policies, intended or otherwise, can highlight important lessons. This is instructive when considering commonalities between national contexts but is also important in enabling us to question, critique and challenge dominant logics in spatial planning.

\section{Acknowledgements}

The authors wish to thank Fred Hobma, associate professor building law at the TU Delft, for his valuable comments to this paper. 


\section{References}

Agbonlahor, W. (2015) Developer submits Croydon office conversion plans, Available at www.planningresource.co.uk/article/1358503/developer-submits-croydon-office-conversionplans (Accessed: 06.09.16)

Allmendinger, P. and Haughton, P. (2013), 'The Evolution and Trajectories of English Spatial Governance: 'Neoliberal' Episodes in Planning', Planning Practice and Research 28 (1): 2-26

Arcadis (2013). Duurzame transformatie van kantoren naar woningen. Arcadis: Rotterdam.

Baker, J. (2016), 'Housing and Planning Act 2016: Essential guide to PIPs', http://nlpplanning.com/blog/housing-and-planning-act-2016-essential-guide-to-pips-may2016/ (Accessed: 22.11.16)

Bell, S. and Hindmoor, A (2009) Rethinking Governance: The centrality of the state in modern society (Cambridge University Press: Cambridge)

Booth, P. (2003) Planning by Consent: The Origins and Nature of British Development Control (Routledge: London)

Brounen, D. and Jennen, M (2009) 'Local office rent dynamics', The Journal of Real Estate Finance and Economics 39 (4): 385-402

Brouwer, J.J. (1994) Kantorenmarkt en stadsstructuur (Rodopi: Amsterdam)

Brouwer, H.J. (2014) Land Policy and Vacancies in the Metropolitan Amsterdam Office Market, in: Nozeman, E.F. and Van der Vlist, A.J. (Eds.) European Metropolitan Commercial Real Estate Markets (Springer: Berlin Heidelberg)

Campbell H, Ellis H, Henneberry J, Gladwell C. (2000) 'Planning obligations, planning practice, and land-use outcomes', Environment and Planning B: Planning and Design 27(5) p.759-775

Carpenter, J. (2014) 'Special report: Charge of the conversions', Planning Resource (Accessed: 27.11. 14)

Carpenter, J. and Geoghegan, J. (2016), 'Ministers rule out extension of affordable housing mechanism', Planning Resource, 31 March 2016 (Accessed: 11.04.16)

Clifford, B. and Tewdr-Jones, M. (2013) The collaborating planner? Practitioners in the neoliberal age (Policy Press: Bristol)

Croydon Metropolitan Centre (2015) The Croydon Monitoring Report, available at www.croydon.gov.uk/monitoringreport (Accessed: 29.08.16)

Croydon Planning Service (2014) Interview, 19.11.2014

Cullingworth, B. and Nadin, C. (2014) Town and Country Planning in the UK (15 ${ }^{\text {th }}$ Ed.)

(Routledge: London and New York)

Davy, B., (2005) Bodenpolitik. In: Ritter (Ed.), Handwörterbuch der Raumordnung. ARL, Hannover, 117-130. 
Department for Communities and Local Government (2011) A plain English guide to the Localism Act 2011 (a: London)

Department for Communities and Local Government (2012) National Planning Policy Framework (DCLG: London)

Department for Communities and Local Government (2013) Royal Assent for Growth and Infrastructure Act, available at: https://www.gov.uk/government/news/royal-assent-forgrowth-and-infrastructure-act (Accessed: 24.07.15)

Department for Communities and Local Government (2015a) House building statistics (last updated 15 February 2015), available at: https://www.gov.uk/government/collections/housebuilding-statistics\#live-tables (Accessed: 24.08.16)

Department for Communities and Local Government (2015b) Planning applications in England: January to March 2015 (Statistics) Available at:

https://www.gov.uk/government/statistics/planning-applications-in-england-january-to-march$\underline{2015}$ (Accessed: 24.07.15)

Dewar, D. (2016), 'What amended office-to-residential permitted development rights mean for applicants and local authorities', Planning Resource, 18 March 2016.

DTZ (2015) Nederland Compleet Medio 2015, available at https://www.dtz.nl/nl/marktinformatie (Accessed: 24.07.15)

Evers, D. (2015), 'Snakes and Ladders: Implementation and enforcement of national urbanization policy', International Academic Association on Planning, Law and Property Rights Annual Conference, 25-27 February 2015 Volos, Greece

Faludi, A. and Van der Valk, A. (1994), Rule and Order-Dutch Planning Doctrine in the Twentieth Century (Kluwer Academic Publishers: Dordrecht)

Greater London Authority (2014) 'Mayor wants planning exemption to protect London's business districts', Mayoral Press Release 09 October 2014, available at:

https://www.london.gov.uk/press-releases/mayoral/planning-exemption-to-protect-businessdistricts (Accessed 06.09.16)

Green, Z. (2015), The curtailing of London's creative economy, The global urbanist Column available at: http://globalurbanist.com/2015/08/05/the-curtailing-of-london's-creativeeconomy (Accessed 01.12.15)

Gunn, A. and Vigar, G. (2012), 'Reform processes and discretionary acting space in English planning practice, 1997-2010', Town Planning Review 83 (5) 533-552

Hajer, M.A. and Zonneveld, W. (2000), Spatial Planning in the Network Society-Rethinking the Principles of Planning in the Netherlands, European Planning Studies 8 (3) 337-355

Hartmann, T., Spit, T., (2015) Dilemmas of involvement in land management - Comparing an active (Dutch) and a passive (German) approach. Land Use Policy 42, 729-737.

Healey, P., McNamara, P., Elson, M. and Doak, J. (1988) Land Use Planning and the Mediation of Urban Change (Cambridge University Press: Cambridge)

HM Government (2016) Housing and Planning Act. 
Hobma, FAM. (2013), 'Verdere bevordering van de transformatie van kantoren naar woonruimte', http://www.bouwrechtonline.nl/ (Accessed: 01.07.15)

House of Commons Communities and Local Government Committee (HCCLGC) (2014) Operation of the National Planning Policy Framework, Fourth Report of Session 2014-15, (The Stationery Office Limited: London)

Johnston, B. (2016), 'The Housing and Planning Act 2016 Digested: Updated 16 June 2016', Planning Resource, 16 June 2016

Koppels, P.W., H. Remøy and S. El Messlaki. 2011. Door leegstand huren lager bij de buren. Real Estate Research Quarterly (10) no. 3, September 2011.

Legislation.gov.uk (2012), The Neighbourhood Planning (General) Regulations 2012, available at: http://www.legislation.gov.uk/uksi/2012/637/contents/made (Accessed 06.09.16)

Lichfield, N. and Darin-Drabkin, H. (1980) Land Policy in Planning (Allen and Unwin: London)

London Borough of Croydon (2013) Croydon Local Plan and Strategic Policies CLP1 (Adopted April 2013) LB Croydon: London

London Councils (2015) The Impact of Permitted Development Rights (London Councils)

LSH (2015) Activating the Workplace Office Market 2015 Available at: http://www.Ish.co.uk/commercial-property-news/2015/04/conversion-of-offices-intoresidential-apartments-gathers-pace (Accessed 24.07.15)

National Audit Office (NAO) (2014) Financial sustainability of local authorities (NAO: London)

McAllister, P., Street, E. and Wyatt, P. (2016), 'An empirical investigation of stalled residential sites in England', Planning Practice and Research 31 (2): 132-153

MacLennan, D. (1982) Housing Economics: An Applied Approach (Addison Wesley Longman: London)

Ministry of Infrastructure and the Environment (2011) Summary National Policy Strategy for Infrastructure and Spatial Planning, Making the Netherlands competitive, accessible, liveable and safe. Available at https://www.government.nl/topics/spatial-planning-and-

infrastructure/documents/publications/2013/07/24/summary-national-policy-strategy-forinfrastructure-and-spatial-planning (Accessed 01.11.2016)

Needham, B., (2006) Planning, law, and economics: The rules we make for using land. (Routledge, Abingdon)

Needham, B., Hartmann, T., (2012) Conclusion. In: Hartmann, Needham (Eds.), Planning by law and property rights reconsidered. Ashgate, Farnham, 219-227.

Parker, G., Street, E., Raco, M. and S. Freire-Trigo (2014), 'In Planning We Trust? Public Interest and Private Delivery in a Co-Managed Planning System', Town and Country Planning Association Journal, December 2014.

Parliament.uk (2016), 'MPs consider Lords amendments to Housing and Planning Bill', Parliamentary Business 03 May 2016, available at:

http://www.parliament.uk/business/news/2016/may/mps-consider-lords-amendments-tohousing-and-planning-bill-/ (Accessed: 06.09.16) 
Pickles, E. (2011), 'Planning reforms boost local power and growth', Available at: https://www.gov.uk/government/speeches/planning-reforms-boost-local-power-and-growth (Accessed 24.07.15)

Pickles, E. (2014), 'Housebuilding', Available at:

https://www.gov.uk/government/speeches/housebuilding (Accessed 16.04.16)

Pierre, J. and Peters, G. (2000) Governance, Politics and the State (Basingstoke: Macmillan)

Planning Guidance (2014) 'What are permitted development rights':

http://planningguidance.planningportal.gov.uk/blog/guidance/when-is-permissionrequired/what-are-permitted-development-rights/ (Accessed: 28.02.15)

Prior, A. and Raemaekers, J (2006), 'Does planning deregulation threaten the environment? The effect of 'permitted development' on the natural heritage of Scotland'. Journal of Environmental Planning and Management 49 (2) pp. 241-263.

Prior, A., Raemaekers, J., Brown, C., Collar, N., O'Neill, C. and Walters, A. (2007) Review of the General Permitted Development Order: Final Report (Scottish Executive Social Research)

Raco. M. and Street, E. (2012), 'Resilience Planning, Economic Change and The Politics of Post-recession Development in London and Hong Kong', Urban Studies 49(5) 1065-1087

Remøy, H. (2010), Out of Office; a Study on the Cause of Office Vacancy and Transformation as a Means to Cope and Prevent (IOS Press: Amsterdam)

Remøy, H., Pallada, R., Hobma, F.A.M. and Franzen A. (2015) Evaluatie convenant aanpak kantorenleegstand Rotterdam, TU Delft, Delft.

Roodbol-Mekkes, P.H., van der Valk, A.J.J. and Korthals Altes, W.K. (2012) The Netherlands spatial planning doctrine in disarray in the 21st century. Environment and Planning A 44 (2) 377-395.

Roth A. (2015) Who Gets What and Why: The Hidden World of Matchmaking and Market Design (William Collins: London)

Rijksoverheid (2012), Convenant aanpak leegstand kantoren, available at: www.rijksoverheid.nl/documenten/convenanten/2012/06/27/convenant-aanpak-leegstandkantoren (Accessed 01.07.15)

Stadig and Minderhoud (2011) 'Herbestemming, regelgeving en gemeente' in Tijdsschrift voor Bouwrecht, 3-2011.

Stb. 2010, 320 (2010) Wet kraken en leegstand: https://zoek.officielebekendmakingen.nl/stb2010-320.html (Accessed: 28.02.15)

Stinner, D.H., Glick, I., Stinner, B.H. (1992) 'Forage legumes and cultural sustainability' Agric. Ecosyst. Environ. 40, 233-248.

Wheeler, B. (2015), 'Spending review: department by department cuts guide', available at: http://www.bbc.co.uk/news/uk-politics-34790102 [accessed 11.04.16]

Yin, R. K. (2013) Case Study Research, Design and Methods (5 ${ }^{\text {th }}$ Ed.) (Sage: London and New York) 